\title{
LOCAL COMMUNITY PARTICIPATION ON INTELLECTUAL PROPERTY RIGHTS PROTECTION OF CIREBON BATIK
}

\author{
Josefhin Mareta \\ Law and Human Rights Research and Development Agency \\ E-mail: josefhin@gmail.com
}

\begin{abstract}
Legal protection of batik art owned by local communities cannot be totally implemented in the legal system of intellectual property rights. The implementation of legal awareness by batik artisans in protecting the traditional knowledge and use of legal effort for the protection of intellectual property is still low. This study was conducted to analyze the participation of local people in the protection of intellectual property rights of Cirebon batik. This study employed qualitative research methods. Based on the results of the study, it is concluded that Cirebon local government have provided legal counseling on the protection of intellectual property rights yet the participation of batik artisans is still low due to the assumption of batik as communal property. Hence, local regulations are necessarily needed to assure intellectual property rights of Cirebon batik.
\end{abstract}

Keywords: community participation, intellectual property rights, cirebon batik

\begin{abstract}
Abstrak
Perlindungan hukum terhadap motif seni batik yang dimiliki oleh masyarakat komunal sulit diwujudkan dalam sistem hukum hak kekayaan intelektual yang bersifat individual. Implementasi kesadaran hukum masyarakat pengrajin batik dalam melindungi pengetahuan tradisional dan menggunakan upaya hukum guna perlindungan hak kekayaan intelektual masih rendah. Penelitian ini dilakukan untuk mengetahui partisipasi masyarakat lokal dalam perlindungan hak kekayaan intelektual batik Cirebon. Penelitian ini menggunakan metode penelitian kualitatif. Berdasarkan hasil penelitian, disimpulkan bahwa pemerintah daerah Kabupaten Cirebon telah memberikan penyuluhan hukum mengenai perlindungan hak kekayaan intelektual namun partisipasi pengrajin batik masih rendah dikarenakan adanya anggapan bahwa batik adalah milik komunal, sehingga diperlukan pembentukan peraturan daerah yang dapat menjamin hak kekayaan intelektual batik Cirebon.
\end{abstract}

Kata kunci: partisipasi masyarakat, kekayaan intelektual, batik cirebon

Introduction

In a global economy, intellectual property rights is seen as trade issues involving the interaction of 3 (three) main aspects, there are intellectual property, commercialization, and legal protection. It means that the right becomes important when an intellectual work will be commercialized so the owner of the intellectual work requires formal legal protection to guard their interests to obtain the benefits from the commercialization of their intellectual work. The creation of intellectual work requires legal protection including in the form of intellectual creativities or ideas.

$\Omega$ This study is a research result of 2015 funded by Law and Human Rights Research and Development Agency Number: PPH.1-UM.02.07-900.
Traditional knowledge is innovations, creations, and cultural expressions generated and maintained for the generations by indigenous people or a local community or individuals in local communities of a country. Indonesia is a country, rich of traditional knowledge, either in the form of traditional medicine such herbs and animals or artistic creations such as crafts, music, and dance.

Batik is a native craft of Indonesian people passed for generations, and related to the aspects of people's life. Besides its cultural values, batik has economic value. The various creation of batik shows the batik artisans interest to preserve and introduce batik to the public. 
As a result, it will increase the value of batik as a unique economic product.

The regulation on copyright in Indonesia has been providing protection for batik art since the enactment of Law Number 7 Year 1987 on the amendment of Law Number 6 Year 1982 on Copyright. Then, by the ratification of the TRIPs agreement through Law Number 7 Year 1994, Indonesia has an obligation to adapt national legislation in the field of copyright because they have ratified the Berne Convention for the Protection of Literary and Artistic Works, which enhance the provisions of copyright through Law Number 12 Year 1997 and Law Number 19 Year 2002 about Copyright. ${ }^{1}$

Substantially, Law Number 19 Year 2002 on copyright has a weakness in terms of multiple interpretations in Article 2 (2) of Law Number 19 Year 2002 on Copyright. The reality indicates that Law Number 19 Year 2002 on Copyrights has some weaknesses in protecting folklore. Batik art is highly potential Indonesia cultural heritage yet it finds it difficult to realize the legal protection of batik art owned by a communal society in the legal system of Intellectual Property Rights, especially the individual one. $^{2}$

Among the four batik centers in West Java, Cirebon is the oldest one that brings big influence on batik development of other areas in West Java. Batik Cirebon has a diverse number of patterns, and rich of values of science (cognition), values of sense, intuition or the unconsciousness, values of ideas, and values of message or value of life which may consist of the moral, social, and religious values. ${ }^{3}$

Cirebon batik grows not only influenced by royal batik but also coastal batik patterns. Batik productions spread across several villages;

1 Sarianti, “Tinjauan Hukumtentang Kerajinan Tangan Sarung Donggala sebagai Produk Indikasi Asal”, Jurnal Ilmu Hukum Legal Opinion. Edition 6 Vol. 2, 2014, Palu: Universitas Tadulako, page 16.

2 Yennv Eta Widvanti. "Perlindungan Hukum Atas Motif Batik Malangan Sebagai Warisan Budava Bangsa”. Jurnal Risalah Hukum, Vol. 9 No. 2, December 2013, Samarinda: Faculty of Law Universitas Mulawarman, page 196.

Irin Tambrin, "Batik Cirebon: Tinjauan Ornamen Batik Trusmi Cirebon”, Jurnal Seni Rupa, Vol. 2 No. 4, May 2002, Bandung: Sekolah Tinggi Seni Rupa dan Desain Indonesia, page 2 . among them are Trusmi Village, Trusmi Wetan, and Trusmi Kulon, Plered Subdistrict. There are about 4,408 workers who every day rely on this craft industry by the production reaching around Rp. 80,622,800,000 (rupiahs). ${ }^{4}$

Implementation of legal awareness by batik artisans to preserve and protect traditional knowledge and legal effort for intellectual property protection is still low. Policy makers and legal decisions in both local and central level have not formulated a policy in the form of legislation to accommodate the aspirations and interests of the community.

Community empowerment is an effort to actualize the potentials owned by the community. The emphasis of community empowerment approach is the emphasis on the importance of independent local communities as a system to organize themselves. This empowerment approach is expected to give a role to the individual and not as an object but as a subject of development that will determine the future of society and life in general. ${ }^{5}$

Empowerment that fully involved community participation or community becomes the most profitable option in the future. At least based on the potential they have as stated by David Osborne and Ted Gabler, among other members of the community will provide a greater commitment; people know the problems faced by citizens deeper; people are more able to provide the settlement of any fundamental problem; the active role of $\mathrm{NGO}$ in the provision of goods and services, while the government role in paying attention and encouragement; government services provided to the public more efficient, effective and participatory; and people are more able to see the potential of each citizens. ${ }^{6}$

4 Data from Industry and Trade Department of Cirebon Region, 2015

5 Fathurrahman Fadil, "Partisipasi Masyarakat dala m Mu syawarah Perencanaan Pembangunan di Kelurahan Kotabaru Tengah", Jurnal Ilmu Politik dan Pemerintahan Lokal, Vol. 2 No. 2, Year 2013, Banjarmasin: FISIP Universitas Lambung Mangkurat, page 30.

6 I wan Noor, "Deontologi Pemerintahan Daerah di Indonesia (Oase Akuntabilitas Politik dalam Perspekt if Partisi pasi Politik)", Jurnal Politika, Vol. I, No. 2, October 2010, Semarang: Post graduate Program Universitas Diponegoro, page 19. 


\section{Problem}

Based on this background, the problem is formulated: how the effort to protect the intellectual property rights of Cirebon batik and how the community participation in the protection of intellectual property rights of Cirebon batik.

\section{Research Method}

This research is an empirical law research. The research method is selected since the authors made use of empirical law case studies in the form of community legal behavior. The approach is qualitative approach to collect information, formulate relevant questions and then link it to the given theories and principles. Technique of data collection was done through the study of literature by reviewing documents, legislation, studies, books, other literature, and field studies by conducting interviews and distributed questionnaires to Cirebon batik artisans. Then based on the obtained data, a qualitative analysis of the theories regarding the protection of intellectual property was conducted. Further, it analyzed how the effort to protect intellectual property on Cirebon batik and community participation in the protection of intellectual property of Cirebon batik.

\section{Discussion}

\section{Efforts of Cirebon Batik Protection}

As an effort of intellectual property protection of Cirebon batik, until 2015, the government of Cirebon have documented 400 batik patterns. In doing so, the local government in 2008 made a Batik Cirebon book containing history, Cirebon people and traditional batik patterns both royal and coastal patterns. ${ }^{7}$ Documentation process is an effort to prove that traditional knowledge belongs to particular community. It is done to preserve the cultural heritage of local people who live and grow naturally, which could prove that a particular cultural heritage did come and be part of the Indonesia social life. Documentation is based on the un-

\footnotetext{
Casta and Taruna, 2008, Batik Cirebon: Sebuah Pengan tar A presiasi, Motif dan Makna Simboliknya cetakan ke1, Cirebon: Culturaland Tourism Comunication Ins titu tion of Cirebon Region, Page 92.
}

derstanding that cultural expressions and traditional knowledge do not require registration because it is already in the public domain in Indonesia. ${ }^{8}$

In 2005, Cirebon administrative registered 100 batik patterns, 70 out of which cannot be registered due to folklore patterns. The registered patterns exclude the protected creation referring to Article 12 (1), letter i Copyright Law Number 19 Year 2002 since folk culture is an expression of folklore that belongs together and is automatically protected by the state. Due to the absence of Government Regulation on the implementation of copyrights held by the state as mandated by Article 10 (4), these works will be recorded as expressions of folklore or works of popular culture from the area or region concerned, in this case is Cirebon. ${ }^{9}$ As stated in Article 38 of Law Number 28 Year 2014 on Copyright, the copyright of the traditional cultural expressions is held by the state and the state is obligated to register, preserve, and maintain traditional cultural expressions. Never-theless, according to the Cirebon administrati-ve, the pattern is not a classical batik design but modern one.

Batik art in Article 40 of Law Number 28 year 2014 on Copyright is one of protected artworks. Law Number 28 year 2014 on Copyright explains that batik artwork is contemporary batik motif which is innovative, contemporary, and modern. The work is protected because it has artistic value, in terms of image, style, and color composition. Still, the law does not regulate what is meant by the motif of classical or modern motifs, so that there are no clear boundaries on traditional patterns and modern patterns or new creations.

8 Devi Rahayu, "Perlindungan Hukumterhadap Hak Cipt a Motif Batik Tanjungbumi Madura", Jurnal Mimbar Hukum, Vol. 23 No. 1, February 2011, Yogyakarta: Facult y of Law Universitas Gajah Mada, page 122.

9 The Letter from Direktur Hak Cipta, Desain Industri, Desain Tata Letak Sirkuit Terpadu dan rahasia Dagang Di rektoral JenderalKekayaan Intelektual Kementerian Hukum dan HAM to Direktur Industri Sandang, Dir ekt or at Industri Kecildan Menengah Departemen Perindust rian on Permohonan Pendaftaran Ciptaan on September $4^{\text {th }}$, 2008. 
According Riyanto's opinion, traditional batik is batik that has a pattern and style bound by certain rules and predetermined pattern and relatively constant or stagnant while modern batik is like traditional batik but patterns and ornaments are indefinite. ${ }^{10}$ One of the requirements for copyright protection is the creation must be original (never exist) but it is the result of the realization of creator's intellectual abilities through his creations so he deserves the right to acquire the copyright. ${ }^{11}$

In 2014, the registration of 4 (four) patterns the local government did improve moral rights to batik artisans and economic rights for the government. In this case, the economic rights require other people who want to trace or imitate the patterns to request permission to the local government while for moral rights, batik artisans can put brand or label as a sign that the particular pattern has been registered.

Moral rights as defined in Article 5 of Law Number 28 year 2014 on Copyright, is one's inherent and permanent right, including with or withut putting his name on the the copy with respect to the use of creation to the public. Meanwhile, according to Article 8 of Law Number 28 year 2014 on Copyright, economic rights allow copyright holders over creation to issue, duplicate in al its forms, distribute and copy them. Everyone who has economic rights shall obtain the permission of the creator or copyright holder. In case of viola-tion of economic rights, the local administrative can ban the products for sale.

According to Law Number 28 year 2014 on Copyright, economic right shall require a reward received by the creators or owners (royalties). By its economic right, the copyright holder or the owner rights who suffered losses economic rights has a right to re-ceive compensation. Compensation in the form of payment of money is charged to violators of

10 Sutriyanto dan Veronika Kristanti PL, "Kajian Visual Ba tik Hokokai Pekalongan Mot if Lereng, Bunga dan Kupu", Jurnal Kriya Seni, Vol. 11 No. 2, July 2014, Surakarta: Institut Seni Indonesia, page 154.

11 Yuliana Diah Waesiki Susi Irianti, "Prinsip Keadilan dalam Pemanfaatan Varietas Tanaman Lokal”, Jurnal Hukum dan Masyarakat, Vol. 13 No. 2, April 2014, Jayapura: Faculty of Law Universitas Cenderawasih, page 75. economic rights creators, copyright holders and/ or owners of that related rights (Article 1 Law Number 28 year 2014 on Copyright).

\section{Local People Participation in Protection of Cirebon Batik Intellectual Property}

Community empowerment especially batik artisans done by education and guidance need to increase people awareness and understanding namely to teach the public about the meaning and skills for the effective change. ${ }^{12}$ By active participation batik artisans are expected to understand and solve problems regarding intellectual property on its batik products. To determine the participation of batik artisans through their understanding of intellectual property protection for the products, a questionnaire was distributed to Cirebon batik artisans (30 people).

Table 1. Cirebon Batik Artisans Understanding

\begin{tabular}{|l|c|}
\hline \multicolumn{1}{|c|}{ Question } & $\begin{array}{c}\text { Percentage } \\
\text { (\%) }\end{array}$ \\
\hline $\begin{array}{l}\text { Iraditional knowledge or traditional } \\
\text { culture. }\end{array}$ & $80 \%$ \\
\hline $\begin{array}{l}\text { Intellectual property (copyrights, pa- } \\
\text { tents). }\end{array}$ & $50 \%$ \\
\hline $\begin{array}{l}\text { Intellectual property registration } \\
\text { process }\end{array}$ & $13.33 \%$ \\
\hline Cirebon batik pattern ownership & $100 \%$ \\
\hline $\begin{array}{l}\text { The origin of Cirebon batik pattern } \\
\text { creation }\end{array}$ & $30 \%$ \\
\hline $\begin{array}{l}\text { New creations in Cirebon batik pat- } \\
\text { terns }\end{array}$ & $100 \%$ \\
\hline Overseas marketing of Cirebon batik & $56.67 \%$ \\
\hline $\begin{array}{l}\text { Cirebon batik purchases by foreigners } \\
\text { to be resold overseas in large num- } \\
\text { bers }\end{array}$ & $60 \%$ \\
\hline $\begin{array}{l}\text { Cirebon batik motif imitation by ot- } \\
\text { her regions }\end{array}$ & $50 \%$ \\
\hline $\begin{array}{l}\text { batik artisans initiative to report the } \\
\text { imitation to the government }\end{array}$ & $0 \%$ \\
\hline $\begin{array}{l}\text { A requirement of regulation gover- } \\
\text { ning the protection of batik products }\end{array}$ & $100 \%$ \\
\hline $\begin{array}{l}\text { A requirement of strict penalty im- } \\
\text { posed to the imitator of the batik } \\
\text { products }\end{array}$ & $96.67 \%$ \\
\hline $\begin{array}{l}\text { The sale decrease due to Cirebon } \\
\text { batik imitation }\end{array}$ & $13.33 \%$ \\
\hline $\begin{array}{l}\text { Source: The results of the questionnaire, } \\
\text { (n) }\end{array}$ & \\
\hline
\end{tabular}

12 Eko Prasojo, "People and Society Empowerment: Pers pekt if Membangun Partisipasi Publik", Jurnal Ilmiah Administrasi Publik, Vol. 4 No. 2, 2003, Malang: Faculty of Administration Universitas Brawijaya. 
As an effort to increase public participation, Cirebon regency government regularly provides legal counseling regarding intellectual property protection to the batik artisans including legal protection of intellectual property and Intellectual Property Right (IPR) registration process. Most of the batik artisans attended the counseling although few of them understand the registration process. Batik artisans understanding of copyright registration is only limited through the Department of Industry and Trade of Cirebon, and is free of charge. This lack of understanding is influenced by their various educational background. As Sastoproetro Santoso said that education, literacy, poverty, status, social status, and have a faith in themselves are factors that influence people's participation, in this case, their understanding of intellectual property protection. ${ }^{13}$

According to the respondents, Cirebon batik ownership belong to Cirebon people passed over generations with a recognizable patterns although nowadays there is a development of modified Cirebon batik patterns. This ownership raises their awareness to continue preserving batik for future generations. It also requires local government's role in the conservation efforts including opportunity to market batik widely. Most respondents told thay they have sold Cirebon batik abroad, one of which is done by joining batik exhibitions abroad, exporting and selling batik products to foreigners to be marketed overseas.

Batik preservation efforts by continuing to develop traditional batik patterns raise some imitating practice among batik artisans. According to them, this practice does not exactly duplicate existing patterns; it may look different by adding a bit of other pattern. Nonetheless, they do not intent to report the pratice to the local government.

In traditional communities, the practice of imitating is something appreciated not viola-

\footnotetext{
13 Sigit Sapto Nugroho, “Kajian Hukum Hubungan Undang Undang Nomor 10 Tahun 2004 tentang Pembentukan Peraturan Perundang-Undangan dengan Peraturan Dae rah", Jurnal Konstitusi, Vol. 1 No. 1, June 2011, Madiun: FKKP-Faculty of Law Universitas Merdeka, page 33.
}

tion. ${ }^{14}$ This value does not correspond to the concept of HKls in terms that every individual utilizes their intellectual products and the rights are granted as a reward for creativity and trigger for innovation and invention. In contrast, traditional or indigenous communities view prioritizes the interests of the community as a whole that includes individual ownership on folklore and origin cultures. ${ }^{15}$ The imitating practice causes the artisans did not register the copyright. Even the effort to register a copyright lead to internal conflict among them as happened in village Trusmi Batik community. ${ }^{16}$

The lack of awareness to register the creation is also due to the assumption that batik is a communal property so that it difficult to be registered as an individual. Afrillyana Purba stated that the protection of folklore or tradetional cultural expression in the provisions of the copyright has drawbacks; there is a requirement of individual creators in the copyright while in a local community folklore is claimed as communal property. Copyright regime deals with the protection of the commercial aspects of rights within a limited time while the issue of traditional knowledge protection is the issue of the cultural heritage protection of a particular community associated with the protection of cultural identity that is permanent. ${ }^{17}$

The imitation of batik patterns decrease the Cirebon batik sales. Thus it raises a requirement to formulate a regulation governing the protection of the batik products, and the provision of strict penalty to the perpetrators of $\mathrm{Ci}$ rebon batik imitation. It is also considered important by local governments to protect the batik artisans who make batik using wax and fine canting or stamped canting stamp and not for printed batik through the manually printing pro-

14 Agus Sardjono, 2006, Hak Kekayaan Intelektual dan Pengetahuan Tradisional, Bandung: PT Alumni, page 405.

15 Winda Risna Yessiningrum, "Perlindungan Hukum Indikasi Geografis sebagai Bagian dari Hak Kekayaan Intelekt ual”, Jurnal IUS, Vol. 3 No. 7, April 2015, Mataram: Faculty of Law Universitas Mataram.

16 Casta dan Taruna, loc.cit.

17 Afrillyana Purba, dkk, 2005, TRIPs-WTO dan Hukum IPR Indonesia: Kajian Perlindungan Hak Cipta Seni Bati Tradisional Indonesia cetakan pertama, Jakarta: PT Rhineka Cipta, pages 318-319. 
cess or machine printing. This is in line with the definition of batik acknowledged by UNESCO, the cloth or clothing made by wax resist technique including the use of certain unique patterns.

Community empowerment is common responsibility between people and government. Yet it is the community as the subject of empowerment who must play an active role, and speak up their aspirations for the good process of empowerment. Community empowerment in the process of increased law enforcement involves knowledge and understanding of the content of the legal norms, obedience and adherence of society to the legal norms and legal behavior patterns of society itself.

In their participation, the initiative is taken by the community itself, guided by their own way of thinking, using instruments and processes (institutions and mechanisms) that they can assert effective control. Government as facilitator is obliged to provide learning and knowledge for the community to build an independence level in the law enforcement of intellectual property.

\section{Conclusion}

Cirebon administrative have attempted to provide protection for its batik products through documentation and registration of Cirebon batik patterns. The obstacle emerges since the registered batik patterns belong to communal folklor and it is an expression of folklore that belong together and automatically protected by the state. The registration raises moral rights and economic rights that provide legal protecttion for batik artisans in terms of exclusive ownership and utilization on objects or creations.

The participation of batik artisans in the protection of intellectual property on the batik products is known through their understanding of Intellectual property rights protection and ef-forts to continue preserving Cirebon batik pro-ducts. However, the lack of legal awareness proven by the practice of imitating and plagiarizing of batik patterns persist due to their conventional view which more prioritizes the in- terests of the community as a whole and the notion that batik is a communal property.

\section{Suggestion}

In the process of registration of $\mathrm{HKI}$ on $\mathrm{Ci}$ rebon batik products, local governments need to take inventory in terms of the differentiation between traditional batik patterns and modern batik patterns. It does not only ease the process of registration but also prevent it from imitating practice.

The protection of intellectual property on products such as Cirebon batik needs to be realized through the formulation of local regulations. It is necessary to regulate provisions concerning plagiarism and grip motif that can be said as a plagiarism. Community participation is required in the formation of local regulations in order to enhance community law awareness and the established appropriate legal norms in accordance with the local community aspirations as the owner of traditional knowledge and culture.

\section{References}

Afrillyana Purba. Et.al. 2005. TRIPs-WTO dan Hukum IPR Indonesia: Kajian Perlindungan Hak Cipta Seni Bati Tra-disional Indonesia cetakan pertama. Jakarta: PT Rhineka Cipta;

Casta and Taruna. 2008. Batik Cirebon: Sebuah Pengantar Apresiasi. Motif dan Makna Simboliknya cetakan ke-1. Cirebon: Cultural and Tourism Comunication Institution of Cirebon Region;

Fadil, Fathurrahman. "Partisipasi Masyarakat dalam Musyawarah Perencanaan Pembangunan di Kelurahan Kota-baru Tengah". Jurnal Ilmu Politik dan Pemerintahan Lokal. Vol. 2 No. 2. Year 2013. Banjarmasin: FISIP Universitas Lambung Mangkurat;

Irianti, Yuliana Diah Waesiki Susi. "Prinsip Keadilan dalam Pemanfaatan Varietas Tanaman Lokal". Jurnal Hukum dan Masyarakat. Vol. 13 No. 2. April 2014. Jayapura: Faculty of Law Universitas Cenderawasih;

Noor, Iwan. "Deontologi Pemerintahan Daerah di Indonesia (Oase Akuntabilitas Politik dalam Perspektif Partisipasi Politik)". Jurnal Politika. Vol. I. No. 2. October 
2010. Semarang: Post graduate Program Universitas Diponegoro;

Nugroho, Sigit Sapto. "Kajian Hukum Hubungan Undang-Undang Nomor 10 Tahun 2004 tentang Pembentukan Peraturan Perundang-Undangan dengan Peraturan Daerah". Jurnal Konstitusi. Vol. 1 No. 1. June 2011. Madiun: FKKP-Faculty of Law Universitas Merdeka;

Prasojo, Eko. "People and Society Empowerment: Perspektif Membangun Partisipasi Publik". Jurnal Ilmiah Administrasi Publik. Vol. 4 No. 2. 2003. Malang: Faculty of Administration Universitas Brawijaya;

Rahayu, Devi. "Perlindungan Hukum terhadap Hak Cipta Motif Batik Tanjungbumi Madura". Jurnal Mimbar Hukum. Vol. 23 No. 1. February 2011. Yogyakarta: Faculty of Law Universitas Gajah Mada;

Sardjono, Agus. 2006. Hak Kekayaan Intelektual dan Pengetahuan Tradisional. Bandung: PT Alumni;

Sarianti. "Tinjauan Hukum tentang Kerajinan Tangan Sarung Donggala sebagai Produk Indikasi Asal". Jurnal Ilmu Hukum Legal Opinion. Edition 6 Vol. 2. 2014. Palu: Universitas Tadulako;

Sutriyanto dan Veronika Kristanti PL. "Kajian Visual Ba-tik Hokokai Pekalongan Motif
Lereng. Bunga dan Kupu". Jurnal Kriya Seni. Vol. 11 No. 2. July 2014. Surakarta: Institut Seni Indonesia. page 154.

Tambrin, Irin. "Batik Cirebon: Tinjauan Ornamen Batik Trusmi Cirebon". Jurnal Seni Rupa. Vol. 2 No. 4. May 2002. Bandung: Sekolah Tinggi Seni Rupa dan Desain Indonesia;

The Letter from Direktur Hak Cipta. Desain Industri. Desain Tata Letak Sirkuit Terpadu dan rahasia Dagang Direktoral Jenderal Kekayaan Intelektual Kementerian Hukum dan HAM to Direktur Industri Sandang. Direktorat Industri Kecil dan Menengah Departemen Perindustrian on Permohonan Pendaftaran Ciptaan on September $4^{\text {th }}$. 2008;

Widyanti, Yenny Eta. "Perlindungan Hukum Atas Motif Batik Malangan Sebagai Warisan Budaya Bangsa". Jurnal Risalah Hukum. Vol. 9 No. 2. December 2013. Samarinda: Faculty of Law Universitas Mulawarman;

Yessiningrum, Winda Risna. "Perlindungan Hukum Indikasi Geografis sebagai Bagian dari Hak Kekayaan Intelektual”. Jurnal IUS. Vol. 3 No. 7. April 2015. Mataram: Faculty of Law Universitas Mataram. 